\section{Muller B}

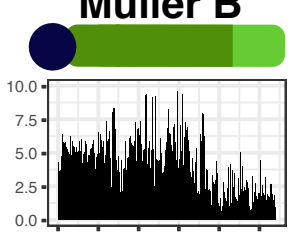

Young Male
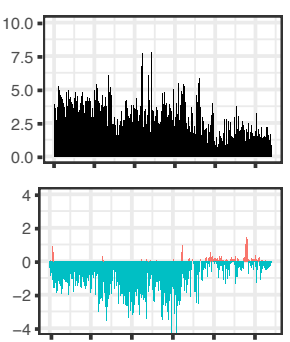

Muller E
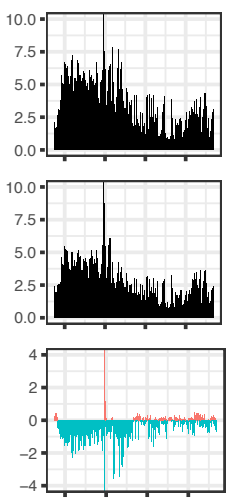

Muller B
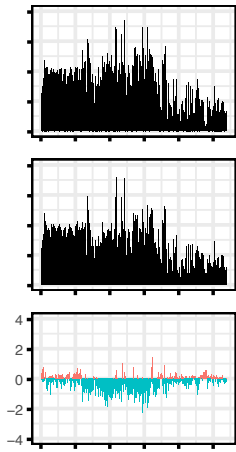

Muller E

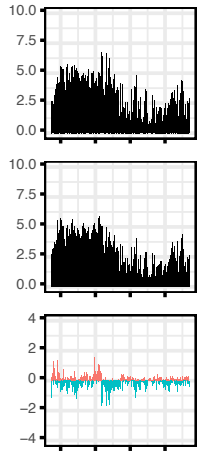

Old Male

Old-Young

Young Male

Old Male

Old-Young

Old Female

Old-Young

Old Female
Muller AD
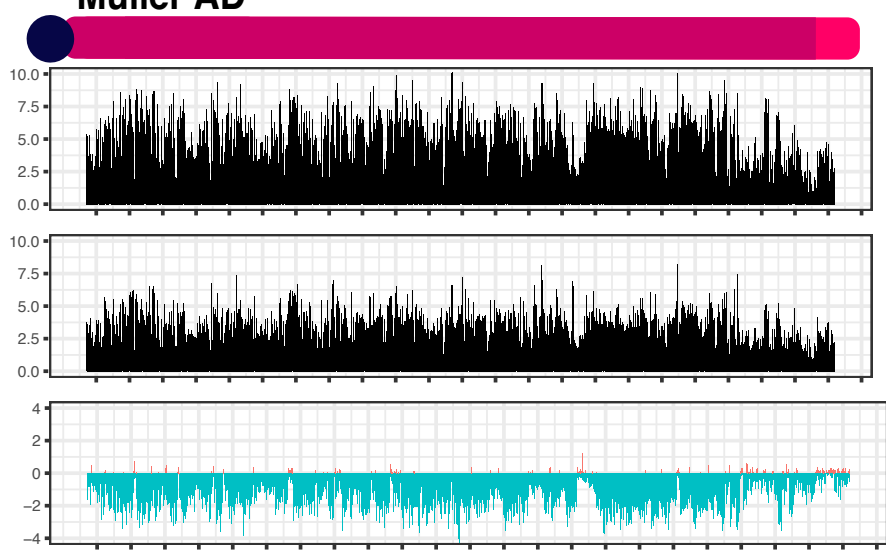

\section{Neo-X (Muller C)}
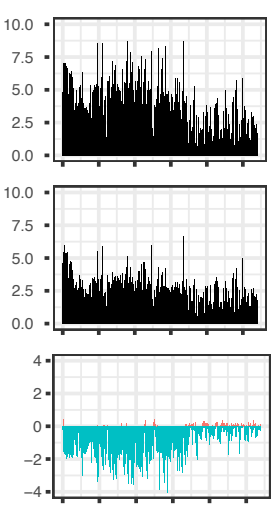

\section{Muller AD}

Young Female
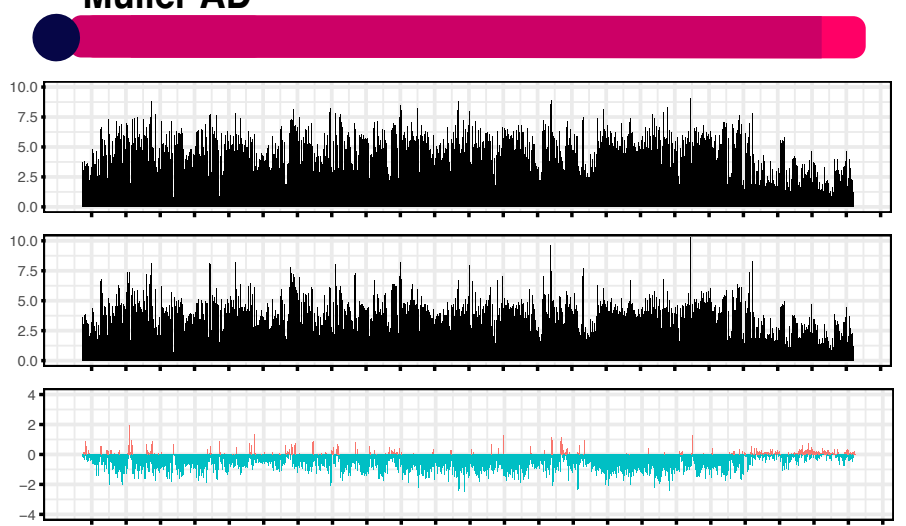

\section{Neo-X (Muller C)}

Young Female

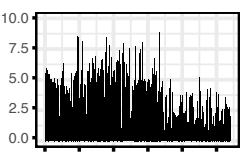

Figure S7: Heterochromatin loss at pericentromeres is more pronounced in males compared to females. 